During the 1980s, the French media proclaimed the death of feminism, but although the 1970s women's movement had demobilised, feminists were still active in issue-specific groups, in academia and within the institutions of the state. Paying careful attention to the difficulties associated with defining feminisms and national feminisms in particular, this article situates an analysis of French feminism since the 1980s in a context of growing international feminist dialogue and activism and a renewed debate about the meaning of feminism. It focuses on the question of separatism and on changing relations between theory and practice, asking how feminists can act for change and form effective coalitions with men and with other movements. It argues that feminism is plural and often fragmented and diffuse. Feminism is shaped by local social, economic, political and cultural factors and by exchanges of people and ideas, and any analysis of feminist theory and activism needs to take these into account. 


\section{Feminism: National and International Perspectives}

Dr. Gill Allwood

Dept. of Modern Languages

Nottingham Trent University

Clifton Lane

Nottingham NG11 8NS

gill.allwood@ntu.ac.uk
Dr Khursheed Wadia

Division of History, Politics \&

International Studies

School of Humanities, Languages \&

European Studies

University of Wolverhampton

Wolverhampton WV1 1SB 


\section{$\underline{\text { Introduction }}$}

In France as elsewhere in the industrialised West, the 1960s and 1970s were marked by enormous change in terms of the range of behaviour and choices allowed to women, the attitudes of both men and women in respect of what women were capable of doing and of the rights they were entitled to claim. The idea of equality between men and women became more legitimate and led to swift changes in legislation related to women's status in the home and at work.

Such social and political change was in part effected by the second wave feminist movement which emerged in the late 1960s and early 1970s and which struggled to change gender relations. The personal fact of one's sex became an area of political struggle as feminists called into question the thinking that sex and gender were legitimate constraints on the right to self-determination. There were high expectations that gains made in the 1970s would continue. However, in the 1980s the return of conservative governments and the ensuing triumph of neo-liberal policies in major world economies (USA, Japan, Germany), leading to market deregulation and a greater orientation towards competitiveness, meant that progressive policies established in the 1970s came under threat. The dilemma of whether to act to protect achievements or to fight for more was one that faced feminists throughout the developed world.

The tensions brought about by this dilemma produced splits within second wave movements and initiated two important processes. The first, a result of the choice made by some feminists to enter into dialogue with the state as a means of protecting gains 
made in the 1970s, was the institutionalisation of feminism. In France this institutionalisation consisted of, on the one hand, the establishment of the Ministry of Women's Rights (MWR), under the aegis of the Socialist government of 1981-1986 and, on the other hand, the entry of feminism into the academy. The second process was the demobilisation of the feminist movement and the decision of individuals or groups of feminists to remain autonomous and to continue defending women's rights and challenging male dominated power relations and structures. The unfolding of these twin processes led to repeated media discussion over the future of feminism in the 1980s. It became fashionable to talk of the demise of feminism and of its replacement by a postfeminist culture in which women had achieved equal status with men and therefore no longer had reason to engage in the kind of militant feminist activism that had marked the 1970s.

However, as the twentieth century has drawn to a close there has been a resurgence in women's activism in favour of social, economic and political change. Some of this activism has taken place within autonomous movements where gender interests and related demands have coincided with broader social and political goals. ${ }^{1}$ Other activists, identifying themselves as feminist, have demanded change which would not only improve women's socio-economic and political status but also, at the same time, call into question men's dominant position in society. Moreover, this resurgence in women's activism in the industrialised world has been accompanied by the emergence of new feminisms in the former Eastern block countries of Europe and within the developing world, in particular parts of Latin America, Africa and the Indian subcontinent. This has 
led to a growing body of literature on feminism in these parts of the world and to a challenging of definitions of feminism established in the 1970s, in the industrialised West. $^{2}$

The resurgence of women's activism world-wide has also produced cross-continent exchanges of theory and practice which have been expressed formally in international congresses such as the 1995 and 2000 UN-sponsored conferences on women in Beijing and New York respectively. The result of all this activity has been a renewed debate about feminism, its defining characteristics, its principal actors and its state of play globally. The main aim of this article is to contribute to this debate through an examination of French feminism.

\section{Definitions}

Feminism has taken many forms over time and place and according to social, political and cultural context. It is neither fixed nor homogeneous, and is cut through by conflict and division around class, ethnicity, sexuality, and ideology. Feminists disagree about their goals, orientation and strategy. They disagree about their relation with women as a group; indeed, they disagree about whether women constitute a group. So how do we decide what to include in a discussion of current expressions of feminism in France?

The danger of constructing a water-tight definition is that it is exclusionary. It sets up barriers, admitting the 'right' kind of feminism and excluding the 'wrong' kind. On the other hand, a definition with too few restrictions is meaningless. It is not possible to rely 
on self-definition: we cannot simply call feminist all those who claim the term.

Conversely, we cannot refuse to call groups and individuals feminist simply because they do not apply the term to themselves. For analytical purposes, there has to be a set of objective criteria, even if this brings with it a number of problems.

One of the main problems of definition lies in the conflation of women's activism, women's movements and feminism. ${ }^{3}$ The automatic connection made in some definitions between women's activism and women's movements and/or feminism may lead to the following difficulties: first, that the (non-gendered) nature of the activism of specific groups of women whose primary affiliation may be to other movements (labour, civil rights or national liberation movements) is concealed; second, that the activism of women who reject women's movement or feminist ideas or who work against the extension of women's rights, as in the case of anti-abortion activists, is wrongly understood.

As far as feminism and women's movements are concerned, there are undoubtedly, and more often than not in real life, vast overlaps between the two, sometimes to the extent that it becomes difficult to separate them. However, there is a definitional difference to be made. Women's movements and feminism are said to be 'characterised by the primacy of women's gendered experiences' ${ }^{4}$ Women's movements and feminist movements can also share the following characteristics: self-definition and organisation, issue articulation and resolution, more often than not a connection with progressive, left-wing ideologies and politics, the capacity to reveal and challenge the norms, values, injustices and inequalities in dominant structures and processes which may lead to a redefinition of the composition 
and workings of social, economic, political and cultural institutions. However, feminism can be distinguished from women's movements by its '... challenge of patriarchy. [It subscribes to a] gendered power analysis of women's subordination and contest[s] political, social, and other power arrangements of domination and subordination on the basis of gender'. ${ }^{5}$ So whereas women's movements may only be interested in renegotiating existing hierarchies in order to gain an equal place for women (for example, movements in favour of gender quotas or parity), feminism will question the basis on which such hierarchies rest. While this difference is fundamental, the separation of the two can be problematic in real life. So for the practical purpose of being able to select examples of feminism and feminist activity later on, it will be accepted that feminism can and often does inspire and inform the strategy and action of women's movements whose primary goals may not be to challenge patriarchy. ${ }^{6}$ Hence, the discussion could include groups or movements with the explicit goal of undermining patriarchy but also those which advance women's interests with a view to achieving equality for women. For the purposes of this article then, the definition of feminism is stretched to cover not only 'theory and practice which aim to change the power relations between men and women', but also 'attempts to achieve equality between men and women, to improve the status of women, and to fight against their systematic oppression by men'. ${ }^{7}$ Feminism differs from the theory and practice of women's groups and organisations which have none of these aims and which may be non-feminist or antifeminist (for example, pro-maternity/antiabortion groups); it differs from the political activities of women in mixed groups and organisations which are not undertaken with these aims; and it differs from research 'on' 
women which does not aim to challenge the gender order and contribute to a politics of social transformation.

In addition to the problems outlined above, there are others associated with the notion of a feminism that is specifically French. At its best, comparative political science and political sociology can draw out the commonalities and specificities of theory and practice in carefully contextualised studies in two or more countries. At its worst, however, it can reduce the research object in each country to its lowest common denominator, accentuating the differences and smoothing over the commonalities across the countries studied. The naming of national feminisms can suggest that they are internally homogeneous, that there is a French feminism, a British feminism, etc. In the case of French feminism, there is the now well-known misuse of the term by English and American literary theorists who, by applying it either exclusively to Julia Kristeva, Hélène Cixous and Luce Irigaray, or to a slightly larger selection of theorists, obscured the theory and practice of the entire grassroots feminist movement as well as the work of numerous feminist theorists and academics (Christine Delphy, Michelle Perrot, Michèle Le Doeuff, Colette Guillaumin to name but a few).

Furthermore, it can be problematic to talk about French feminism given the enormous increase, over the last 20 years, in international exchanges of not just ideas and thinking but also in the movement of people. Hence, feminist ideas and theories have been described as forming part of 'ces théories nomades qui vont de personne à personne, d'une période à une autre, se transformant selon les nouveaux usages, et parfois les 
disciplines'. ${ }^{8}$ Furthermore, the movement of people has resulted in the establishment of significant migrant communities in France. Migrant women or those of migrant origin, who make up half of these communities, have established activist associations of which some have a clearly feminist orientation (for example Les Nanas Beurs and Voix d'elles Rebelles). While these associations are French by association law, many of their members and most visible activists see themselves as feminists in France rather than as representatives of French feminism. Moreover, given the social, economic and political status of the majority of migrant women and women of migrant origin, their associations remain on the margins of the mainstream of feminism in France. Therefore, the term and concept 'French feminism' can in fact apply to many ideas, theories and strategies that were conceived by feminists outside France. It can also ignore feminism and feminists in France who are not French or who do not identify themselves with French feminism.

However, there is nevertheless something which is still 'French feminism', and which is determined by the historical, social, political and cultural context in which is has developed. Failing to recognise the existence of feminisms which are different because of these specific factors would result in the mistaken suggestion that there is a universal feminism, untouched by its origins and environment. Given the dominance of white western feminism in terms of publications, conference contributions, access to the media and international organisations and policy makers, this so-called universal - or unnamed - 'feminism' tends to be white, western, and middle-class. Interestingly, during the 1980s, there was a tendency to situate what was misleadingly named 'French feminism' as the exotic Other against this unqualified standard 'feminism'. 
As one of the aims of this article is to contribute to the debate about renewed feminist activity and activism within a globally comparative framework, it makes sense to talk about French feminism while keeping in mind the associated problems discussed above and while ensuring that the discussion is firmly rooted in the social, political and economic context

\section{French feminism in the 1980s}

French feminist activism died down at the end of the 1970s as part of the general demobilisation that accompanied first, the disappointing defeat of the left in the 1978 elections, and second, the disappointing reality of a Socialist government elected in 1981 and veering to the right from 1982. The predominance of US-led, neo-liberal thinking was to have a constraining effect on French economic policy of the 1980s, and the gradual rise of the extreme right combined with it to produce a reactionary backlash making it impossible for a movement as heterogeneous as the French women's movement (MLF) to continue effective activism. The entry of some sections of the MLF into institutions of the state - most notably the Ministry of Women's Rights, established in 1981 under the new Socialist government, and the academy - marked the beginning of institutionalisation and also contributed to the wearing down of autonomous feminism. This was interpreted by many activists as the death of the movement. ${ }^{9}$ Noting its decline, the French media announced the end of feminism, represented as a vulgar Anglo-Saxon aberration, and the return of French-style femininity. 
However, while visible contentious collective action had declined, it would be wrong to say that feminism had ended in the 1980s. Autonomous feminism survived in the form of single issue campaign groups such as the Collectif féministe contre le viol, founded in 1985 or the Collectif féministe contre le racisme, in 1984. Struggles were also waged against proposed legislation that could have had the effect of pushing women back towards the home. Hence feminists demonstrated in significant numbers, against policies undermining abortion rights (1981 and 1986), and easy access to municipal crèches (1985 and 1986). Furthermore, they initiated and led workplace actions (e.g. women carried out strikes in 1982, in favour of better working conditions, against private employers such as Bella, makers of dolls and Bekaert Cokerill, steel products maufacturers, against the imposition of part-time work). These examples represent a small part of autonomous feminist activity in the 1980s. It is worth noting two things here: first, that most of this activity was defensive in nature; second, that during the 1980s, feminists whose roots lay in the 1970s movement began to think for the first time about forging alliances with other campaigns over issues such as anti-racism and peace, given that other social movements provided the only pools of potential recruits from which activist feminism could be renewed when the circumstances demanded it.

\section{French feminism in the 1990s}

The 1990s marked a sharp contrast with the previous decade with the resurgence of feminist activity and activism. A number of factors contributed to this: first the return of right-wing government to France in a situation of economic recession and high unemployment; second the increasing threat posed by the Front National which had 
established itself as a credible electoral force since 1984; third, a growing awareness, fostered by various European and international events, of France's poor record in promoting women in the political arena.

During the 1980s, France under the Socialists had joined the 'neo-liberal-' club' of industrial nations with reluctance and reservations. However, the new regime of the right, under the premierships of Edouard Balladur (1993 to 1995) and Alain Juppé (1995 to 1997) positively embraced social and economic policies that governments in the USA, Britain and Germany had long welcomed and which had produced the most deleterious effects on large numbers of women and other economically deprived groups.

In 1993, the Balladur government wasted little time in passing a quinquennial employment law which opened the way for various 'flexible' working measures at company level. The removal of any reference to the working week meant that employers were able to adjust working patterns to suit company needs and demands. Women (already occupying over 80 per cent of part-time posts ${ }^{10}$ ) were mainly at the receiving end of changes in working patterns and felt that they were being pushed back into the home through the introduction of further part-time posts and short-term contracts. In highly feminised companies such as France Telecom, EDF/GDF (Electricité de FranceGaz de France) feminist trade unionists initiated walk-outs, strikes and demonstrations against the plan in 1993 and 1994. In 1995, with the election of Jacques Chirac to the presidency, and under the premiership of Alain Juppé, the right felt in an even stronger position to push for radical socio-economic reforms. The Juppé social security reform 
plan of 1995 brought five million protesters onto the streets of Paris and other cities. The protest movement included the women's 'manif du 25 [novembre]' coordinated by CADAC (Coordination des associations pour le droit à l'avortement et à la contraception) which brought together 30-40,000 protesters. ${ }^{11}$ This demonstration was in support of reproductive rights, employment and real equality between women and men, and was against the resurgence of religious fundamentalism. ${ }^{12}$ The protests against government policy in the mid 1990s had the effect of raising feminist consciousness in revealing to women the precariousness of their position.

In addition to government policy, the electoral successes of the Front National, its increasing presence in sites of power, ${ }^{13}$ its anti-feminist discourse and practice and its links with violent anti-abortion groups further fomented the resurgence of feminism.

Finally, a number of European and international initiatives and events in the late 1980s and early 1990s also revealed to French women that their representation in important, decision-making sites of power was extremely low compared with that of women in other industrialised nations. Amongst these initiatives were the following: a 1989 seminar organised by the Council of Europe on parity in political institutions; the establishment, in 1992 by the European Commission of a 'women in decision-making' network of experts whose job was to collate gender statistics, to identify and analyse barriers to women's political advancement and to provide examples of good practice in breaking down male domination in politics; the 1995 Beijing conference on women highlighted the advances that women still had to make in order to gain equality with men. All of this had 
the effect of galvanising French women into taking action not only to protect rights already won but also to push for greater equality and autonomy.

Apart from the strikes and protests between 1993 and 1995 against government policy, at the forefront of French feminist action was CADAC ${ }^{14}$ which brought together various feminist associations, the MFPF (Mouvement Français pour le Planning Familial which had declared itself a feminist organisation in the mid-1980s), women's sections or commissions from the main trade unions and political parties. Responsible for a number of high-profile campaigns, CADAC lobbied intensively to urge court action against violent anti-abortion groups, ${ }^{15}$ free supply of contraceptive pills for young women, ${ }^{16}$ and publicly-funded status for abortion clinics. ${ }^{17}$ In addition, CADAC organised one of the largest women's rights demonstrations (manif du 25 [novembre]) ${ }^{18}$ at the height of the 1995 protests against the Juppé plan while CNDF - the Collectif national des droits des femmes (formed in January 1996 as an offshoot organisation of CADAC) prepared the March 1997 Assises nationales pour les droits des femmes, organised over two days, with the aim of sustaining feminist mobilisation around a number of themes and issues. ${ }^{19}$ Events flowing from the discussions of the working groups established at the Assises nationales included the French sector of the Marche mondiale des femmes in 2000 and a demonstration on the International Day against Racism in March 2001.

Towards the end of the 1990s, the media began to present more favourably what they described as a new wave of feminism. The demonstration for women's rights in November 1995, the fourth UN Conference on Women in Beijing in 1995, and the 
Marche mondiale des femmes against poverty and violence in 2000 were all cited as evidence that feminists were remobilising. The debate around the equal representation of men and women in politics and, later, around equality at work, helped to change the climate of relentless opposition to feminism, which had dominated the 1980s and early 1990s.

The two groups which received the most media attention were Mix-Cité, headed by a very articulate, politically astute and photogenic Clémentine Autain (with her copresident Thomas Lancelot-Viannais who, in the media reports, plays a supporting role) and the Chiennes de Garde, comprising articulate, politically astute and photogenic personalities including Florence Montreynaud, Roselyne Bachelot and Isabelle Alonso. Feminism was back in fashion, on condition that it was not too subversive, although the Chiennes de Garde and Mix-Cité cannot be considered equivalents in this respect: MixCité has as an explicit aim the overthrow of patriarchy, whereas the Chiennes de Garde aims to ensure that 'les hommes et les femmes se parlent poliment [...] J'ai été élevée à me contrôler. Je veux qu'eux aussi apprennent à se maîtriser ${ }^{20}$. The characteristics of the 'new feminism' which appealed the most were that it was young and non-separatist.

It is not the intention here to describe every aspect of contemporary French feminism. To do so would involve a survey of the numerous disparate groups, for example les Nanas Beurs, Voix d'elles Rebelles, les Sciences Potiches, le Collectif féministe contre le viol, which continue to focus on issue-specific campaigns and actions around, for example, reproductive rights, domestic violence, prostitution, sexism in advertising, the rights of 
migrant women and women of migrant origin, female genital mutilation..., as well as the smaller number of groups which organise specifically as feminist groups, for example, Mix-Cité and Marie pas Claire. It would involve an analysis of the participation of feminists in the mixed organisations CADAC and the CNDF, which originally organised around reproductive rights, but quickly broadened their concerns to incorporate many more aspects of gender and other social relations. It would involve an analysis of the interventions of feminists active in trade unions, political parties, non-governmental organisations, political, legal and economic institutions and organisations. And it would involve a discussion of the cultural impact of feminism in literature, film and the media. And in each case, the discussion would return to the complexities of defining feminism in France. Rather than listing and describing groups, events and debates, we will instead focus on some of the main characteristics of feminism in France and some of its recent changes. These include firstly, non-separatism, and secondly, the cross-fertilisation between feminist theory and practice and between feminism and other social movements.

\section{Non-separatism or 'mixité'}

The autonomous women's movement, which became known as the Mouvement de libération des femmes, formed in the early 1970s largely as a reaction to the subordination of women within organisations on the alternative and far left. It adopted separatism so that the power relations which silenced women in these organisations would not be replicated. Not all feminists left their mixed organisations. Many tried to combine activism on the left with involvement in the MLF, and some feminists argued throughout the 1970s and 1980s and continue to argue today that if patriarchy is to be 
overthrown, then men as well as women must be involved in the struggle. ${ }^{21}$ But the MLF remained separatist until it demobilised and fragmented between about 1979 and 1981, and before 1995, there were few examples of feminists who argued that men should be involved in feminism. New feminist groups which formed after the demise of the MLF were women-only (for example, the Nanas Beurs, formed in 1985, and Marie pas Claire in 1992). The idea of men in feminism was treated with great suspicion. Anne Zelensky reported in 1993 that her willingness to work together with men against male violence was greeted with hostility by other feminists ${ }^{22}$, and researcher and activist around male violence, masculinity and sexuality, Daniel Welzer-Lang, refers to himself somewhat warily as 'anti-sexist' or 'pro-feminist', but not 'feminist'.

Today, feminist groups and feminists as individuals are involved in mixed institutionalised and non-institutionalised groups and organisations. What is most significant, however, is that the core of feminist activism, which is currently located in the CNDF and CADAC, is mixed, as are growing numbers of new feminist groups. The series of women's rights demonstrations which have taken place since 1995 have been organised by the mixed CNDF and supported by large numbers of mixed organisations.

Young feminists in student groups or groups which have splintered from the extreme left, seem to take non-separatism for granted, explaining their ready acceptance of it by the fact that they are the first generation to have experienced an entirely mixed education. They argue that gender relations will not change without men, and that the engagement of men in feminist struggle is no more questionable than the presence of white people in 
anti-racist struggles. Even the numerous groups who do not admit men - for example les Nanas Beurs or les Marie pas Claire - have been keen to stress that while organised along separatist lines, they are far from being anti-men and that their struggle is one which concerns men:

... nous ne voulons pas les castrer. Non, nous ne sommes pas féministes en raison de prétendus problèmes que nous aurions connus dans notre enfance. ... Nous voulons pouvoir parler de problèmes qui peuvent paraître futiles ou triviaux, mais qui se révèlent souvent très politiques et importants quand on arrive à en débattre. En présence d'hommes, ce ne serait pas possible. ${ }^{23}$

Men have signed petitions in favour of parity and against sexist insults directed at public women; they have participated in demonstrations in favour of women’s rights, and a smaller number have joined groups calling themselves feminist. At the same time, however, there is evidence to suggest that women's experience of activism in social movements is still one of subordination, even where their levels of participation are very high, as is the case, for example, in Ras l'Front and Agir ensemble contre le chômage (AC!). Many of the new feminist groups and networks were formed by students or political activists who found they could not address gender issues in their unions or organisations. Maya Surduts writes:

Dans les entreprises, les syndicats sont dominés par les hommes et il est très difficile pour les femmes de faire prendre en compte leurs revendications. C’est vrai aussi dans les mouvements anti-chômage, ou dans d'autres. Partout on a 
tendance à considérer le discours des femmes secondaire. Au sein d'ATTAC par exemple, les rapports de force sont tellement mauvais qu'on ne peut même pas mener la discussion. ${ }^{24}$

And Clémentine Autain remarks: 'Il y a un machisme au sein du mouvement social qui est pratiqué quotidiennement. 25 The media portrayal of men and women harmoniously demonstrating together on a range of social and explicitly gendered issues overlooks these ongoing problems.

\section{$\underline{\text { Movement and Research }}$}

Feminist theory emerged from the practice of the 1970s and was intertwined with it throughout the decade. During the1980s, however, the connections were weaker. Feminist research groups had formed in some universities as early as the mid 1970s, organising conferences and seminars. Individual lecturers offered women’s studies modules where they could, although the vast majority were constrained by the strict disciplinary organisation of French academia, making interdisciplinary studies difficult to integrate. Institutional recognition of feminist research came with the first national conference 'Femmes, Féminisme et Recherche' at Toulouse in 1982, sponsored by the Ministry for Research, the Ministry for Women’s Rights and the CNRS. Following the conference, the CNRS launched a research programme 'Recherches féministes et recherches sur les femmes', and a very limited number of university posts were created. In 1989, a conference on women and the Revolution was held in Toulouse, and this was 
to act as a catalyst for research projects on various aspects of women and the French Republic.

During the 1970s and early 1980s, relations were difficult between feminists who entered the institutions and those who rejected any form of co-option. Acrimonious debates took place around the 1982 Toulouse conference about whether feminist researchers were abandoning feminism and destroying the movement, and in 1989, Françoise Collin described a feminism split in two:

Le féminisme français semble s’être aujourd'hui replié sur deux de ses bords: d’une part les ‘recherches féministes’ dont le colloque de Toulouse a consacré le principe, d'autre part le service social auquel j'assimilierais les groupes d'aide aux femmes battues ou aux immigrées. Entre les deux, malgré certaines initiatives, un grand vide de pensée et d'actions politiques, qui n’est d’ailleurs pas pire que celui dont est affectée la scène politique traditionnelle - celles de partis - comme en a attesté la récente campagne présidentielle. Le féminisme n’est plus ou n’est pas devenu ce terrain commun aux intellectuelles et aux non-intellectuelles, à la réflexion et à l’action, qu’il avait rêvé d’être. Le vide que j'évoquais n’est guère interrogé par les chercheuses, soit qu'elles aient renoncé à changer le monde, soit qu'elles considèrent implicitement qu'une modification profonde du savoir, auquel elles travaillent, entraînera par lui-même le changement du monde. ${ }^{26}$ 
Institutional funding was limited and did not favour overtly feminist research. On the contrary, projects which were supported tended to be ‘about women' rather than feminist, investigating, for example ways in which women (not men) could combine family and work.

In contrast to this, the EU action programmes, within which competitions for research funding were held, appeared far more pro-feminist. French feminist researchers therefore ensured that they were involved in the growing number of European networks established by the Council of Europe and with funding from the European Commission. The Association nationale des études féministes acted as a national relay for European participation. $^{27}$

During the 1990s, feminist research grew in France for a number of reasons and despite some significant obstacles. The growing influence of the EU on French public policy and the availability to French feminist researchers of EU funding had a positive impact, as did the growing popularity of the idea of parity and, to a certain extent, some sort of gender equality.

As part of the preparations for the Beijing conference, the scientific committee responsible for preparing the French delegation, organised an international conference in Paris, inviting feminists and women academics to participate in the organisation and to give papers. For some, this was an opportunity to demonstrate the richness of feminist 
studies in France; for others, it was an example of co-option and an attempt to cover up the fact that the official report was written without consultation with feminist researchers.

The relation between theory and practice is a perennial problem for feminism, and was the subject of debate at the ANEF day conference 'Etudes féministes, militantisme et mouvement des femmes' in $1997^{28}$ where Rita Thalmann asked:

Pour nous, féministes, les droits des femmes s'inscrivent-ils seulement dans une utopie, voire dans un univers aseptisé de recherche ‘objective’ ou dans une réalité impliquant un changement de société? ${ }^{29}$

Interestingly, the contributions of young feminist activists to the ANEF day conference seem to demonstrate that their exposure to women's studies has played a role in raising their feminist consciousness. Many of them came to feminism as a result of their experiences in parties, trade unions or other political organisations, but many also became conscious as the result of their exposure to some sort of women's studies, women's history, or the history of the women's movement, suggesting that there are various ways in which women's studies may have a political impact.

It has been suggested that recent developments in feminist theory and practice may help to bridge the gap between the two. These include participation in non-governmental organisations, international conferences such as Beijing +5 , and international actions 
such as the Marche mondiale des femmes. As Gillian Youngs writes in the International Feminist Journal of Politics:

$[\ldots]$ globalisation $[\ldots]$ is, importantly, $[\ldots]$ a consideration which is fusing the concerns of academics with a whole range of practitioners in government, nongovernment, activist, advocacy and campaigning institutions. It is bringing the thinking of so-called theorists into connection and conversation with so-called practitioners more and more. Curiosity as well as the need to adequately comprehend global processes and their interaction with regional and local processes of various kinds are driving this, in some senses, rebirth of theory in practice and rebirth of practice in theory. ${ }^{30}$

\section{$\underline{\text { Conclusion }}$}

The main aim of this article has been to discuss a particular national feminism, in this case French, with a view to contributing to renewed discussion in France and elsewhere about what feminism is today and how it has changed. Its central argument is that feminism is not a single entity: it is plural and often fragmented and diffuse. Under certain conditions these separate elements may coalesce into a mass movement, but this is just one form feminism may take, not its defining characteristic. The conditions under which feminism evolves in different parts of the world are shaped by local social, political, economic and cultural factors. In addition, they are shaped, and increasingly so, by exchanges of ideas, people, language, laws and so on that take place between 
countries through migration and supranational bodies. Feminism is therefore both rooted in a particular national context and steeped with influences from outside it.

So feminism did not disappear in France in the 1980s, to reappear a decade later, as suggested by certain observers. Rather, it responded to its environment, remobilising in the 1990s, in coalitions with anti-racist, anti-capitalist, anti-heterosexist, antifundamentalist, and environmentalist movements both in France and as part of a more global wave of protest.

While this article has mapped French feminism over the last two decades in the light of the argument above, and highlighted the main questions with which it is concerned today - i.e. acting for change with men, with other movements and bridging the gap between theory and practice - there are still issues which require further discussion. These are: the position of women within movements whose interests concern both women and men and the relation between feminism and such movements; the specificity of women's concerns in France which may not be relevant beyond its borders. Western feminists have realised that they cannot impose a definition either of feminism or of women's needs on women in the developing world. This has implications for western feminists at the level of theory and strategy. At the level of theory, it means recognising the specificity of one's own condition and reaching out to make connections with different women. At the level of strategy, it means forming coalitions in the same way, and there is growing evidence of such coalition-building across social movements in France and with feminists outside France. 
${ }^{1}$ In France, in the late 1980s and 1990s, women formed a significant, visible section of organised or coordinated protests within the French public sector, notably in education, transport and health, against neo-liberal politics embraced by successive French governments which produced a degradation of working conditions, wages and skills on the one hand and an attack on the welfare state on the other hand.

${ }^{2}$ See for example, MOHANTY, C., RUSSO, A. \& TORRES, L., Third World Women and the Politics of Feminism (Indiana University Press, 1991) and BASU, A. (ed.), The Challenge of Local Feminisms: Women's Movements in a Global Perspective (Westview, 1995).

3 See BECKWITH, K., 'Beyond compare? Women's movements in comparative perspective', European Journal of Political Research, 37 (2000), pp. 431-68.

${ }^{4}$ BECKWITH, K., 'Lancashire women against pit closures: women’s standing in a men’s movement', Signs, 21(4) (1996), p. 1038.

${ }^{5}$ BECKWITH, 'Beyond Compare', p. 437.

${ }^{6}$ For a fuller discussion see ALVAREZ, S., 'Advocating feminism: the Latin American feminist NGO "boom"', International Feminist Journal of Politics, 1(2) (1999), pp. 181209. 
${ }^{7}$ ALLWOOD, G. \& WADIA, K., Women and Politics in France 1958-2000 (Routledge, 2000), p. 173.

${ }^{8}$ HIRATA, H., LABORIE, F., Le DOARÉ, H. \& SENOTIER, D., Dictionnaire critique du féminisme (PUF, 2000), p. xiii.

${ }^{9}$ Françoise Picq writes, for example: 'Le ministère des droits de la femme s’est substitué au mouvement des femmes.' See PICQ, F., Les Années mouvement (Seuil, 1993), p. 332.

${ }^{10}$ GAËLLE, L., 'L’Emploi des femmes sous le choc de la dérèglementation', $\underline{\text { Cahiers du }}$ féminisme, 79/80 (1996/1997), pp. 4-6.

${ }^{11}$ Police estimates were 30000, whereas the movement claimed 40000 demonstrators.

12 TRAT, J., ‘Autumn 1995: A Social Storm Blows Over France’, Social Politics (Summer/Fall 1996), pp. 223-36.

13 In 1995, the Front National won control of the southern town councils of Orange, Marignane, and Toulon followed by Vitrolles in a municipal by-election of 1997.

${ }^{14}$ CADAC was formed in 1990. 
${ }^{15}$ In response, the Ministry of Justice issued an order to public prosecutors to bring proceedings against perpetrators of anti-abortion violence. In practice, anti-abortionists were only prosecuted for criminal damage caused to abortion clinic buildings and equipment. Threats of violence and actual violence caused to persons were not pursued.

${ }^{16}$ Two types of contraceptive pill were already supplied free. CADAC's lobbying pushed Edith Cresson's government to allow free supply of a 'third generation' of contraceptive pills which mainly benefitted young women.

${ }^{17}$ This was not achieved nationally but CADAC's support of a five month strike at one clinic in Colombes led to partial victory in that locally, 33 per cent of medical staff time was apportioned to public funds.

${ }^{18}$ The importance of this demonstration cannot be stressed enough as a turning point in the mobilisation of feminist activism.

${ }^{19}$ The agenda consisted of eight themes: the right to abortion and contraception; the position of women in public life; violence against women; poverty, economic instability and immigration; citizenship, secularism and the moral order; the right to work; family policies; the international context.

${ }^{20}$ MONTREYNAUD, F., Libération (11 avril 2000), p. 21. 
${ }^{21}$ Anne Zelensky and Marie-Victoire Louis are prominent examples of this.

${ }^{22}$ See ALLWOOD, G., French Feminisms (Taylor \& Francis, 1998), p. 123.

${ }^{23}$ Les Marie pas Claire in '1968-1998 Mais qu'est-ce qu'elles veulent encore?', FigaroMagazine (16 mai 1998), p. 52.

${ }^{24}$ MENINE, K., ‘Quand les féministes parlent du féminisme’, l’Humanité Hebdo (janvier 2000), p. 13.

25 Ibid.

${ }^{26}$ COLLIN, F., 'Ringard ou ringuèle? La question des stratégies’, BIEF: Bulletin d’information des études féminines, 20(1) (décembre 1989), pp. 163-4.

${ }^{27}$ FOUGEYROLLAS-SCHWEBEL, D., 'L’essor récent de la recherche féministe en France’ in DAGENAIS, H. (ed.), Pluralité et Convergences (les Editions du remueménage, 1999), pp. 393-407.

${ }^{28}$ Bulletin de l'ANEF, 'Etudes féministes, militantisme et mouvement des femmes, supplément au numéro 23, (1997). 
${ }^{29}$ Ibid., p. 23.

${ }^{30}$ YOUNGS, G., JONES, K.B., PETTMAN, J. J., ‘New Spaces, New Politics:

International Feminist Directions’, International Feminist Journal of Politics, 1(1) (June 1999), pp. 1-13. 